\title{
PROPERTIES OF ENGINEERING MATERIALS
}




\section{PROPERTIES OF}

\section{ENGINEERING MATERIALS}

Theory, worked examples and problems

Gladius Lewis

B.Sc.(Eng.), M.Sc., Ph.D., M.Inst.B.E., A.M.I.Corr.T.

Lecturer in the Faculty of Engineering,

University of Zimbabwe, Salisbury

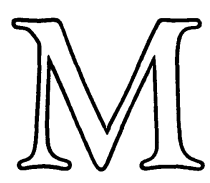


(C) Gladius Lewis 1981

Al1 rights reserved. No part of this publication may be reproduced or transmitted, in any form by any means, without permission.

First published 1981 by

THE MACMILLAN PRESS LTD

London and Basingstoke

Companies and representatives

throughout the world

ISBN 978-1-349-05839-6 ISBN 978-1-349-05837-2 (eBook)

DOI 10.1007/978-1-349-05837-2

The paperback edition of the book is sold subject to the condition that it shall not, by way of trade or otherwise, be lent, resold, hired out, or otherwise circulated without the publisher's prior consent in any form of binding or cover other than that in which it is published and without a similar condition including this condition being imposed on the subsequent purchaser. 


\section{CONTENTS}

Preface

vii

1 MECHANICAL PROPERTIES 1

1.1 True Stress and True Strain 1

1.2 Hardness 3

1.3 Meyer Hardness Analysis 4

2 DIFFUSION 18

3 VISCOELASTICITY 31

3.1 Introduction 31

3.2 Mechanical Mode1s 31

4 COMPOSITE MATERIALS $\quad 40$

4.1 Introduction 40

4.2 Mechanics 40

5 CORROSION 48

5.1 Introduction 48

5.2 Diffusion Rate $\quad 49$

5.3 Concentration Overpotential 49

5.4 Polarisation $\quad 50$

5.5 The Stern-Geary Equation 51

6 OXIDATION 65

6.1 Introduction $\quad 65$

6.2 Oxidation Kinetics $\quad 65$

6.3 Oxidation Thermodyanmics 66

7 CREEP AND CREEP STRESS RELAXATION

$\begin{array}{lll}7.1 & \text { Introduction } & 77\end{array}$

$\begin{array}{lll}7.2 & \text { Creep } & 77\end{array}$

$\begin{array}{lll}7.3 & \text { Creep Stress Relaxation } & 78\end{array}$

8 FATIGUE FAILURE 100

8.1 Introduction 100

8.2 Empirical Formulae 101

8.3 Theories of Failure for Combined Stress 102

8.4 Influence of Stress Concentration on 104

Fatigue Strength
8.5 Utilisation of Fatigue Properties in Design

9 FRACTURE AND FRACTURE MECHANICS 121

9.1 Brittle Fracture 121

9.2 Stress Concentrations 121

9.3 Linear Elastic Fracture Mechanics 122 
10 MISCELLANEOUS TOPICS 142

10.1 The Lever Rule 142

10.2 The Tempering Parameter 142

10.3 Therma1ly Activated Processes 143

$\begin{array}{lll}\text { APPENDIX I } & \text { Further Reading } & 158\end{array}$

APPENDIX II Table of Error Function 160

APPENDIX III Theoretical Stress Concentration 161

Factors 


\section{PREFACE}

A knowledge of the properties of engineering materials is crucial to the safe design and performance of components in service. The subject has, however, not often been treated in a manner which lends itself to easy solutions of problems by undergraduate students. The purpose of this book is to illustrate, in a concise form, the basis of the properties of engineering materials and hence to aid problemsolution. For each topic covered, the format consists of a presentation of the relevant theory in a compact fashion, omitting the wider treatment, followed by a number of worked examples and problems for the reader to solve on his own.

The main reason for this approach is that there are well-written textbooks available which the student can consult for both background material and detailed exposition. This book therefore assumes some basic knowledge of the subject and should be used in conjunction with such textbooks as are listed in appendix I.

I wish to express my thanks to the Senates of the Universities of London, Cambridge and Nottingham for permission to reproduce questions from their past examination papers. The range of questions presented here will make the book useful to all levels of technical college, polytechnic and undergraduate university students. I alone am responsible for the solutions and for the unacknowledged questions. 